\title{
Social Disability and the Public Good
}

\section{Marcia Rioux and Ezra Zubrow}

\section{Well-being and Social Justice as Public Goods}

The ways in which a society provides for people who are more socially and economically dependent and more culturally marginalized throws into sharp focus the problems of the public domain as a political construct (Drache, 1999). Concepts such as well-being and, more broadly, social justice help delineate the state's responsibility in ameliorating disadvantage, social isolation, income redistribution, inequality, and ethnic homogenization. The role of the state has, in some cases, been reduced to balancing the competing interests of the monetarist policies, which demand deficit reduction, with the social justice interests of equality, social well-being and the reduction of poverty.

The post-war framework for social justice and well-being recognized that "international economic issues could not be treated in isolation from domestic social change". High unemployment and the lack of effective systems of support were widely perceived as socially, politically and economically unfeasible. They made clear the importance of social well-being as a public good. Security was a key element of the post-war framework, both as a realist concept (Grayson, 1999) ${ }^{1}$ and because the experiences of the Great Depression, the Second World War and the return of veterans brought uncertainty as to whether people could meet their basic needs on their own 
(Grayson, 1999) ${ }^{2}$. Through the depression people faced hunger, homelessness, ill health and disability on a scale not seen before.

The framework for social well-being as a public good, therefore, grew out of the desire to find an alternative to the social and economic upheaval caused by the great depression of the 1930's and the inability of international leaders to achieve a lasting peace after the First World War ${ }^{3}$. These goals were articulated at Bretton Woods (1944) and in the Atlantic Charter of 1941. Both recognized that distributive policies and social justice were international public goods (Kapstein, 1999). They focused on the role of the state in bringing about security, democracy, and opportunity within the context of citizenship.

To the extent that these arrangements would lead to the fulfillment of social and economic goals, social well-being was achievable(Roeher, 1992). World leaders linked economic growth, political stability and social justice, as, for example, in the United Nations Charter.

With the new framework for well-being came a renewed belief in the social, economic and political institutions of society. It made no difference whether they were social democratic or welfare statist states, such as Sweden and Norway, or liberal residual welfare states, such as Canada and Britain or corporatist welfare states, such as Germany, Austria, Italy and France. Because social well-being was in the public domain, it meant that decisions by government were not simply ad hoc, but were the outcome of rational deliberation and strong public administration. Among the most commonly agreed upon elements of the welfare state is that it embodies a public commitment to improve welfare by achieving a greater measure of social equality 
(Korpi, 1983, Ruggie, 1984). Mishra defines the welfare state as the "institutionalization of government responsibility for maintaining national minimum standards" (Mishra, 1984 p. 34). A key goal of the welfare state is to modify market forces so that the well-being of individuals and families is not subject exclusively to their market powe, that is, it is the decommodification of labour (Esping-Andersen, 1985).

Until the mid-seventies, arguably, there was a consensus that "well-being", encompassing basic needs of physical security, civil and political rights and democratic processes, was a public good. In most countries, institutional structures were established that increased government involvement in the management of the economy and in providing for the security of citizens.

But the political winds have changed in the past 20 years, and the result has been that national policies directed to achieving distributive justice are constrained by internal and external economic forces, globalization and a lack of political will.

\section{Well-being as a Reinvented Public Good}

The notion of well-being ${ }^{4}$ as a public good encompasses the recognition of unequal opportunities within the market economy and the need for the state to be proactive in addressing those inequalities (Kaul, 1999). It recognizes that the market and the state have to work together to optimize the prospects for well-being among the least advantaged members and the least advantaged communities by increasing their capacity and their opportunity.

T.H. Marshall observed, in 1950, that the core idea of the welfare state is social citizenship. This is the extension of civil and political rights to the sphere of social 
provision so that there is a general enrichment of life, a reduction in risk and uncertainly and a reduction of social inequality. While the granting of social rights, did not necessarily directly reduce inequality, by conferring a sense of status on individuals through access to services, social citizenship does compete with and even replaces one's class status (Marshall and Bottomore, 1992). This concept of social citizenship finds its moral foundation in liberal notions of justice (Rawls, 1971) in which survival and autonomy are basic needs. There is an obligation on the state to assure that all citizens can meet these needs. Society is compelled, on moral grounds, to compensate those who the market fails and to care for the sick, the elderly, the unemployed and other dependent groups, even if it means sacrificing some economic efficiency to do so. Social goals such as the development of community or social citizenship supercede market-determined goals of efficiency.

Mohan Rao (Rao, 1999a, Rao, 1999b) argues that, as in the case of peace, equity and justice cannot be obtained separately by individual consumers in the market place. There is a strong instrumental role for equity and justice - in helping to jointly provide other public goods, and in defining their prioritization. Thus, eliminating poverty benefits not just the poor, but also the rest of society. It strengthens peace and stability, global health and market efficiency - quite apart from its intrinsic value. Well-being is not predicated on market failure, inclusiveness or cooperative consumption. It is predicated on social justice. This leads to a shift in perspective from "survival" to "sustainability" and is impacted by factors other than market conditions including political, cultural, and historic values.

Resulting from both the ideological and economic crises in the 1970's, social 
expenditure increasingly came to be viewed as an excessive burden. A progressively more hegemonic view of the market led to a breakdown of the consensus about the positive role of government that had guided social policy development for the previous thirty years. Government and the mixed economy were viewed by neo-liberals as the fundamental problem and retrenchment as the effective solution.

It seems clear that the social benefits of the welfare state, which were articulated by the Allies at the end of Second World War have not led to social well-being or to social justice. Market values, as represented in the Washington Consensus, intervened and it became clear that the articulation of social well-being as expressed in social welfare programmes, was insufficient and subject to ideological and economic forces. There remained a social deficit (Osberg, 1990). Well-being, when limited to the securing of civil and political rights; basic needs for income, safety and support; and the exercise of political democracy, was not sufficient to ensure justice or to develop distributive policies. To ensure well-being as a public good requires that the challenges facing governments are managed in ways that satisfy the very diverse elements and interest groups in society. Amongst these elements are included the increasingly complex nature of governing and the need for policy coherence, the need for a foundation for fairness and the rising costs of social welfare (in the form of income support, education, unemployment insurance, and health and social services). Self-determination, democratization, and equality provide the basis for a revised notion of social well-being as a public good in the current context. 


\section{Elements of Social Well-being}

An expanded notion of social well-being would then have six elements (Roeher, 1993). They are security, citizenship, democracy, self-determination, democratization, and equality. The first three are those that were identified in the post-War period. The latter three have strong elements of indivisibility and non-exclusiveness that are characteristic of public goods and fit within an understanding of public goods that encompass social justice and distributive justice. Rao argues that equity and distributional criteria must be at the core of our notion of public goods. "At a minimum, notions of horizontal equity (the equal treatment of equals) and vertical equity (a progressive distribution of burdens) in financing are often invoked" and are indeed necessary for this expanded definition to be achieved.

Self-determination can be defined as the choice and pursuit of aspirations and the development of capabilities, which are made autonomously and free from coercion. It is usually exercised by individuals, communities and societies when their aims are articulated and implemented. Self-determination is important in this "reinvented wellbeing", by allowing the individual to decide, on the basis of self-knowledge, selfmanagement, and resource availability, how they want to lead their lives. In the realm of health, the World Health Organization recognizes the relationship between increased self-determination and control of one's environment, on the one hand and health status, on the other. It also increases human dignity and self worth. In the case of the workplace, when workers are expected to make decisions about their education, training and the organization of their workplace tasks, job motivation increases. Under 
these conditions of self-determination there is a greater potential for innovation, increased productivity, and work satisfaction.

Democratization is the process of enabling the democratic participation of individuals and diverse groups, in a wide scope of decision-making processes that directly affect their lives. It is, in this way, a component of well-being. Democratization involves a constructive politics of recognition (Taylor 1992,1993), equal participation of diverse interests in decision-making, and democratized decision-making in societal institutions. These requirements ensure the cooperative behaviour necessary for the provision of public goods (Rao, 1999a), as people will participate more willingly in a system that they perceive to be fair and equitable. Democratization is important because it requires the mutual recognition of others' aims and needs as a means to providing a counter balance to the abuse of power. Also, it provides a mechanism for social bonding and a basis for agreement on individual limits to self-determination.

Equality, another element of social well-being, has many definitions. As an element of social well-being, it is defined as the absence of barriers to mutual respect and recognition between people "who are equally free from political control, social pressure and economic deprivation" (Lukes, 1980). Equality refers to equality of outcome rather than equality of treatment, thereby incorporating notions of equal enjoyment of well-being, institutional recognition of differences, and accommodation and support to ensure equal freedom to pursue aspirations.

The notion of "well-being" as a public good affects the outcome of public policy in several ways. First, it creates a framework that leads to a redefinition of social conflict and institutionalizes diversity and democratic social bargaining as a basis for decision 
making. Second, not only does it institutionalize social diversity, it moves toward the coordination and integration of economic, social, and environmental policies. It recognizes that sustainable economic growth and social development are integrated problems that cannot be addressed by sectoral solutions. Third, the framework provides a system of measures to index "the social health" of a nation. This results in a change from policy fragmentation to policy coherence.

\section{The Privatization of Social Well-Being}

A strong case can be made for social well-being as a public good in as much as it has such characteristics as equity, shared communal benefits, indivisibility, nonrivalry, and non-excludability. Yet, governments have limited their investment of public funds directed towards its achievement. This disjunction between the political commitment and the economic investment suggests the off-loading of government responsibility to the private domain. Social well-being is increasingly market-driven and privatized. However, because there remains a political commitment to it as a public good, governments have had to rationalize their decisions to reduce their fiscal expenditure. The increasing governmental limitations on expenditures in this area have meant that the public's needs are being met selectively rather than universally. The coherence that social well-being as a reinvented public good offers is being circumscribed by political action rather than by market conditions - political action that rationalizes government disengagement from its own recognition of social justice and social well-being as public goods. 
Deficit reduction, it has been argued by neo-liberal governments, represents a greater common good than the availability of social programs. Individual self-sufficiency has triumphed, as a valued economic and cultural commodity. Consequently social wellbeing, as evidenced in health, culture, equality and equity, has shifted for a significant number of people from a public good to a private good. This shift can be seen in the significant restructuring of the welfare state, away from universal provision based on citizenship rights to provision based on social need. Thus, any prospect of entitlement has been removed. The expectation is an increasing reliance on private provision with a greater emphasis on self-reliance.

Social disability provides an example of the way in which governments have invoked scientific rationalism, economic determinism and philosophic traditions of utilitarianism to shift the responsibility from the public domain to the private domain. The boundary between the public and private domain shifts toward the private, as scientific rationalism and economic determinism comes into play. The rationale is:

- To set or establish a hierarchy of social or cultural goods, which enables one to take precedence over another, in terms of public expenditure, and to use that hierarchy to legitimate the place where the line is drawn between a public and a private good. This economic rationalization, based on a simple notion of utilitarianism, has provided a means to limit social expenditure. (Sen, 1999b, 1999a). Thus, the issue of subsidizing lives becomes, as Martha T. Mcluskey puts it, an aspect of the ideology of efficiency. Welfare and health care are reduced under the rubric of utilitarianism.

- To differentiate between people, based on such characteristics as social status, 
biology or culture and legitimate these criteria as a basis of providing for some and not for others. This limits the state responsibility for disadvantage and leaves it to the market to correct. Scientific rationalization makes it possible for politicians, economists, and policy analysts to use science to justify a particular set of political actions. From this perspective, it is the function of the science to assess the most crucial problems besetting society. For example, Claude Desama, the Chairman of the European Parliament's Committee on Energy, Research and Technology, argued this point at the end of the two-day EC Science Summit staged on October 14-15 in Brussels. He said that research projects ought to be geared more towards stressing the need for science to help work up the new development models that reflect societies overall concerns as well as examining the relationship between research and human activities (Service, 1993).

\section{Social Welfare as a Limited Public Good}

The question of how far the global economic relationship affects national welfare provisions is affected by the power relations behind the nationalist boundaries of welfare obligation and how the movements of capital, as well as labour, affect the potential for welfare provisions. The role of the state, in regulating and correcting inequality, may be either expansive or restrictive, arguably in response to international monetary pressures and to the importance placed on economic efficiency and effectiveness as state goals. Where increasing equality rights entitlement, social well-being, and full employment are 
state social values, the role of the state in providing well-being is much clearer. But recent government redefinition of the boundary between public and private has resulted in greater private responsibility for inequities and increased dependence on the market to correct the imbalances.

\section{Economic Rationalization and Utilitarianism}

From about the end of the First World War to the 1960's, most Western governments established a social safety net that placed the responsibility for care of those who were most disadvantaged in the public domain. High unemployment and the lack of effective systems of support were widely perceived to be socially and economically unacceptable.

For those who could not participate in the labour market, the state made a growing commitment to provide for their security through a number of income programs and social services. Key social security reports of the '40's recommended a full employment economy as a matter of policy, and entitlements to income and social support in the event of illness, old age and unemployment. There were always, however, restrictions to the demand that the state had to bear. In order to limit an openended public responsibility for social justice, governments limited their redistributive policies based on an economic determinism grounded in utilitarian principles. A distinction between the worthy and the unworthy poor provided a means for distinguishing what was the individual and family responsibility and what was a public obligation for social justice and the actualization of social well-being. 
The distinction between worthy and unworthy rationalizes redistribution by placing a ceiling on the demand for excessive social spending on social justice. It provides an indicator of how people are differentiated and the way in which the differences are formulated to affect the public-private differentiation and the subsequent social policy. It is a public good to ensure that those who cannot work and gain a secure income to take care of themselves be provided for by the state, as a matter of social justice. Providing for individual misfortune, to which anyone might be subject, through such factors as age, accidental disability, or unavoidable unemployment is recognized as a public good. But fiscal limits to the obligations of state redistribution on this basis are justified, because the boundary of the public good is drawn such that the state does not have to provide for those who are able to work but are not working. That is, as a matter of economic efficiency, some people who do not have income security will have to fend for themselves. This "monetarist approach" supposedly fosters growth by restraining demand in order to reduce consumption. The focus on markets and free trade is justified because of the belief that growth will eventually "trickle down" to protect the environment and assure minimum standards of health and labor welfare.

In contrast, distributive justice and social well being, as public goods, invoke an ethical principle of fairness, rather than utilitarianism. From this perspective, the rich, the wealthy capital investors or high-income earners can afford to give up more than the poor low-income earner. Utilitarianism, as applied to well-being, represents a break from benefit theory and allows greater taxation in the service of maximum social utility. In other words, it should "... improve the distribution of income and wealth arising from free competition (Schoenblum, 1995.). 


\section{The Upheaval}

By legitimating differences between people's misfortune through categories such as "worthy" and "unworthy", the demands placed on the public sphere are reduced. Only those who are "worthy" will be provided for through the public sphere. As already noted, this legitimates the reduction of public expenditure, but it also makes social well-being a selective public good. The goal of the English Poor Laws ${ }^{5}$ and those modeled after them in many countries established this tradition of a distinction between the worthy poor and the unworthy poor. Through the evolution of this distinction in the succeeding years, the state established some obligation to care for those considered worthy poor. These included people who were old, sick or disabled. The implications of this distinction have most often been analyzed from the perspective of those considered unworthy. These are the 'able-bodied' and 'able-minded' men and women who were considered able to but who were unwilling to work. For those who fell into this category, the welfare state has been minimalist and residual, based on the "less eligibility" principle. Without recognition of the structural factors which have led to unemployment, poverty, ill health and illiteracy, welfare state provision has entangled people and families in a web of meager provision, disentitlement, discretionary benefits, contradictory eligibility rules, surveillance and targeted programs. These have had the effect of entrenching and privatizing rather than ameliorating inequality and social isolation. As many of the poor are seen as 'unworthy' through the lens of the welfare state institutions, provision for this group has remained minimalist and residual. 
Obviously this reduced social cost and delimited what was in the public domain (See Figure 1). 
Figure 1. Economic determinism as a legitimating mechanism for determining the public/ private boundary.

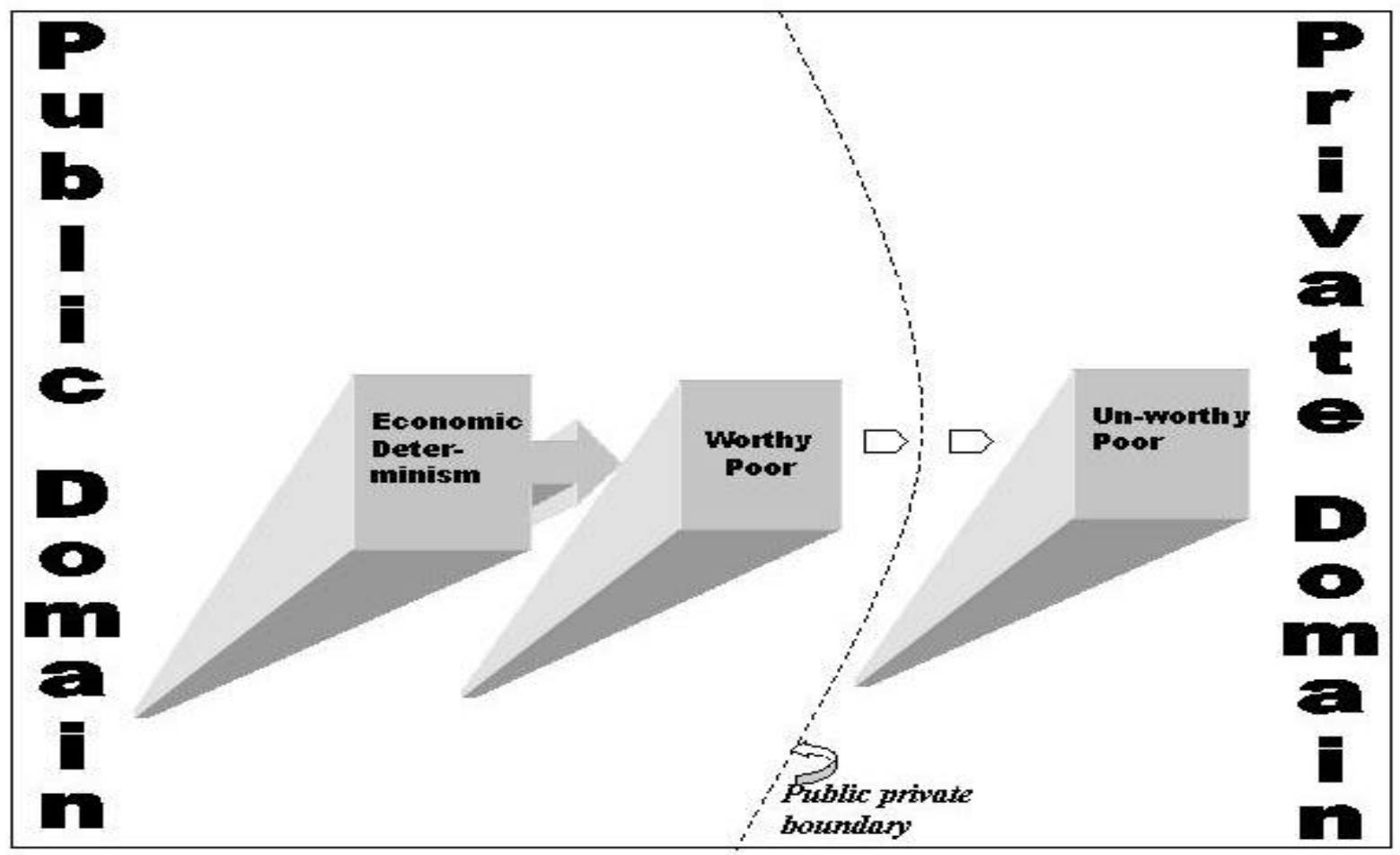

From the perspective of the 'worthy' poor, a different set of obligations was established than for those who were 'unworthy'. These obligations could only be exercised by constructing legal and social differences that have served to legitimate different treatment and obligations between the worthy and the unworthy.

The category of 'worthy' poor has become a double-edged sword for many disadvantaged, marginalized people. Under the legal and social regime of 'worthy poor', people with disabilities, the old and the infirm, become the object of charity, but at the cost of basic social citizenship. Considered incompetent to function in society, this being 
the entrance to becoming 'worthy', there is some public responsibility for the misfortune and for meeting those needs, where for the 'unworthy' the misfortune is private. The social programs and policies for the 'worthy' then become part of the public domain.

In the immediate post-war period, the framework of obligations emphasizing security, citizenship and democracy entrenched the worthy/unworthy [public/private] distinction. These became the pillars of the framework for social well-being [and state obligation] and provided the basis for investment in building the institutional infrastructure for welfare provision. The notion of citizenship, as a broad set of social, economic and political entitlements, was being formulated in this period (Marshall and Bottomore, 1992). However, the figure of the 'citizen', that remained entrenched, was that of the self-made, rational and independent individual exercising basic democratic and legal rights. A democratic state and society was to be constituted by such individuals securing for themselves and doing so largely on their own, the 'good life'. Because many people did not meet the tests imposed by such a concept of citizen (e.g. those with disabilities, old, etc), they were to be taken care of through the 'security' pillar of welfare

Governments established highly targeted and categorical programs, with restricted eligibility requirements to ensure that people were seen to be different and treated differently as the condition for obtaining welfare provision. It is a matter of demonstrating the state's obligation to those in need (the public domain), while the burden on the state is minimized (enlarging the private domain). The result is to increase the private and decrease the public responsibility. Charity, pity and incapacity are within the public domain - simple need is not. The interrelationship of the public and 
private has varied from country to country and the entitlement to the social goods is variable.

Although there was, in some countries, a move towards greater recognition of a wider notion of social justice from the 1960 's to the 1980 's ${ }^{6}$, international global pressures resulted in a retrenchment.

Deficit reduction has become a greater good than social justice and social wellbeing in government priorities. So the balance is shifted to deficit reduction, and individual self-sufficiency is valued as an economic and social commodity. International pressure for deficit reduction has trumped social arguments and a history of welfare "statism" in determining social policy and the public-private division of responsibility for disadvantage.

The promotion of selective poverty programs, as opposed to integral, comprehensive and universal social policies, results from their being compatible with the permanence of basic neo-liberal economic policies and state withdrawal from its responsibilities as the main financier and organizer of social service Given the scarcity of public resources, the argument continues, the way to achieve this objective is through carefully targeted poverty programs that complement the satisfying of social needs through market and family mechanisms .... The end result is the same as that stated by the neo-liberal doctrine: social welfare belongs primarily to the private domain - to markets, family and community - and only when it cannot be resolved in this way should the state intervene and guarantee social minimum using public resources. (Laurell, 1994) 


\section{Social Disability and the Public Good within this Framework}

Scientific rationalism has provided a further state mechanism for recognizing social justice as a public good, but differentiating those whose well-being is a public responsibility from those whose well-being is not. It legitimates the variable boundary between the public domain and the private, leaving it to the market to correct inequalities, and for the family and charities to provide when the inequities are not resolved. Katz (1986)documented an earlier example of what he termed "scientific charity". In the 1870's in the United States, in the public sector, policy was developed to abolish or reduce relief. In the private sector the result was the formation of charity organization societies that attempted to rationalize and systematize philanthropy.

Reformers wanted to do more than cut expenses and purge the able bodied from relief. To these familiar goals, they added a new element: a concerted drive to make relief primarily private. Alarmed by the disorder of American cities in the last third of the nineteenth century, frightened by the spectre of a militant, organized and undeferential working class, the charity organizers responded as harshly as employers and governments confronted with similar problems. The task charity organizers set themselves was to teach the poor that they had no rights. Afraid that relief was turning into a right, the new reformers put all their energy into transforming it back into charity. (Katz, 1986), 58 
Disability benefits and entitlements provide an example of a case in which a particular status can be differentially interpreted as within either the public or private domain. This shows quite clearly how interpretations of political obligation are constructed as a means to justify where the boundary between public and private is drawn.

The case of disability provides a way to identify how the state conceptualises and measures "well-being" for marginalized groups. It provides a vehicle for determining the different legal and social statuses of such populations as well as determining whether the disadvantages of such populations are a private or public responsibility.

The scientific and social justification for political action related to disability can be traced to identifiable and shifting conceptual frameworks. These dissimilar formulations of disability underlie the kinds of policy and programs that can be found in most nations of the world. This suggests that knowledge in this field be created internationally not nationally. While the models of disability have led to different social policy and social responsibility in different countries, there are identifiable commonalties in these spheres that emanate from the particular characteristics of the models themselves.

The following figure (figure 2) provides a general view of the various understandings and formulations of disability. 


\section{Individual Pathology}

Bio-medical approach

(consequence of biological characteristics)
Functional approach (consequence of functional abilities and capacities)
-Treatment: through medicine and bio-technology

-Prevention: through biological/genetic intervention or screening

- Social responsibility: to eliminate or cure disability
-Treatment: through rehabilitation services

-Prevention: through early diagnosis and treatment

-Social responsibility: to ameliorate and provide comfort

\section{Social Pathology}

\section{Environmental approach}

(consequence of environmental factorsand service arrangements)

-Treatment: through increased individual control of services and supports

-Prevention: through elimination of social, economic and physical barriers

-Social responsibility: elimination of systemic barriers

\section{Human rights approach}

(Consequence of social organization and relationship of individual to society)
-Treatment: through reformulation of economic, social, and political policy

-Prevention: through recognition of condition disability as inherent in society -Social responsihility to noroxide nolitical and social entitlements

Figure 2: Formulations of disability

There are four identifiable social and scientific formulations of disability reflected in the treatment of persons with disability in law, in policy, in programs and in human 
rights instruments. Two of them emanate from theories of disability that postulate it as a result of individual pathology (a deficit model) and two that postulate it as a result of social, legal and economic conditions. How disability is perceived, diagnosed and treated, scientifically and socially, is reflected in assumptions about the social responsibility towards people with disabilities as a group. The assumptions or postulates about disability are not mutually exclusive nor have they been temporally chronological.

Scientific formulations of disability based on an individual pathology have a number of common characteristics:

- $\quad$ they approach disability as a field of professional expertise

- $\quad$ they use, primarily, a positivist paradigm

- $\quad$ they emphasize primary prevention including biological and environmental conditions

- they characterize disability as incapacity in relation to non-disabled persons; a comparative incapacity they distinguish disability and its attached costs as an anomaly and social burden

- $\quad$ they portray the inclusion of people with disabilities as a private responsibility - they depict the individual condition as the primary point of intervention.

The social obligation attached to the characterization of disability as a biomedical or biological condition has conventionally been limited to medical diagnosis and treatment, including medical or genetically directed therapeutic interventions. For those who cannot be cured or rehabilitated, the conventional models of care have been institutions and other segregated housing and all-encompassing service provision centres. Until quite recently, people with disabilities were expected to make no 
contribution to society. They were in many cases considered a danger to society (see (Cohen, 1983, 1985,Canada, 1979, Sutherland, 1976) and because they were characterized as without potential, families were encouraged to place their children in institutions. Their well-being would be provided but limited to the basic necessities of food, shelter and clothing. The alternative for families was to keep their children at home where they would have familial contact and care but the state was under little obligation to provide services, supports or financial resources.

The second of the two formulations of disability as an individual pathology is a bio-functional or rehabilitation approach. Like the bio-medical approach, the underlying presumption is that the deficit stems from an individual condition or pathology. The feature that distinguishes this approach from the biomedical is that the way of understanding the condition is in relation to the impact that the biological condition has on the individual's functional capacity.

The social responsibility in dealing with disability as a functional abnormality is to provide ways to ameliorate the condition to the extent that the negative effects can be reduced and incapacity to function can be reduced. This leads to the development of systems of assessment, habilitation and measures to improve self-care and social skills. This social responsibility derives principally from a sense of charity and benevolence (and in some cases, an economic calculation of the social cost that attaches to being dependent in society). The definition of the hierarchy of needs to ameliorate the functional inability is left to professionals, who are attributed, with the skills and knowledge to determine what is in the best interests of the individual and what will be most beneficial. 
The following table (Mackelprang, 1999) shows the role of professionals within a context of a formulation of disability grounded in individual pathology in both the biomedical and functional approaches. 
Professional Responses to Disability

\begin{tabular}{|c|c|c|c|c|c|}
\hline Perspective & Problems & $\begin{array}{l}\text { Role and } \\
\text { Definitions of } \\
\text { the Person }\end{array}$ & Professions & Controls & $\begin{array}{c}\text { Expectation of } \\
\text { the Person }\end{array}$ \\
\hline$\overline{\text { Medical }}$ & IIlness, sickness & Patient & $\begin{array}{l}\text { Medicine, } \\
\text { nursing, } \\
\text { physical } \\
\text { therapy }\end{array}$ & $\begin{array}{l}\text { Physician with } \\
\text { consultation of } \\
\text { allied health } \\
\text { professionals }\end{array}$ & $\begin{array}{l}\text { Passive } \\
\text { recipient of } \\
\text { treatment }\end{array}$ \\
\hline $\begin{array}{l}\text { Mental } \\
\text { Health }\end{array}$ & $\begin{array}{c}\text { Mental illness, } \\
\text { personality } \\
\text { deficits }\end{array}$ & Patient, client & $\begin{array}{l}\text { Psychiatry, } \\
\text { psychology, } \\
\text { mental health, } \\
\text { social work }\end{array}$ & $\begin{array}{c}\text { Psychiatrist, } \\
\text { clinical } \\
\text { psychologist } \\
\text { with } \\
\text { consultation of } \\
\text { other } \\
\text { professionals }\end{array}$ & $\begin{array}{c}\text { Passive } \\
\text { recipient of } \\
\text { treatment, } \\
\text { compliance } \\
\text { with treatment } \\
\text { plans }\end{array}$ \\
\hline Vocational & $\begin{array}{l}\text { Unemployment } \\
\text { ability due to } \\
\text { personal } \\
\text { problems }\end{array}$ & Client, student & $\begin{array}{l}\text { Educational } \\
\text { psychology, } \\
\text { vocational } \\
\text { rehabilitation, } \\
\text { rehabilitation } \\
\text { psychology }\end{array}$ & $\begin{array}{c}\text { Rehabilitation } \\
\text { counselor, job } \\
\text { coach }\end{array}$ & $\begin{array}{c}\text { Follow } \\
\text { vocational } \\
\text { plans }\end{array}$ \\
\hline
\end{tabular}




\begin{tabular}{|c|c|c|c|c|c|}
\hline Educational & $\begin{array}{c}\text { Learning, } \\
\text { attention and/or } \\
\text { behavioural } \\
\text { deficits }\end{array}$ & Student & $\begin{array}{c}\text { Special } \\
\text { education, } \\
\text { behavioural } \\
\text { therapy, } \\
\text { educational } \\
\text { psychology }\end{array}$ & $\begin{array}{c}\text { Resource/ } \\
\text { special } \\
\text { education } \\
\text { counselors, } \\
\text { educational } \\
\text { psychologists }\end{array}$ & $\begin{array}{c}\text { Remedial } \\
\text { learning and } \\
\text { improving } \\
\text { behaviour }\end{array}$ \\
\hline $\begin{array}{l}\text { Social } \\
\text { service }\end{array}$ & $\begin{array}{l}\text { Social worker, } \\
\text { social service } \\
\text { worker, financial } \\
\text { worker }\end{array}$ & Client & $\begin{array}{l}\text { Social work, } \\
\text { social services }\end{array}$ & $\begin{array}{c}\text { Social worker, } \\
\text { financial } \\
\text { worker, } \\
\text { eligibility } \\
\text { worker }\end{array}$ & $\begin{array}{c}\text { Being } \\
\text { compliant and } \\
\text { remaining } \\
\text { eligible }\end{array}$ \\
\hline
\end{tabular}

From: Mackelprang, (1999) p.12.

In both formulations of disability originating in an individual pathology, labelling or diagnosing the physiological or psychological state is important. It is a means of determining the individual pathology or functional disabilities. It is a basis for undertaking curative or remedial treatment. And it provides both the market and the public sector with the means to confine or delimit its financial commitment. Given the "medicalization" of disability, many instruments have been developed for the purpose of diagnosis such as the International Classification of Impairment, Disability and Handicap (ICIDH), the Diagnostic Statistical Manual (DSM 3), the International Classification of Disease (ICD 10), and various IQ tests. On the basis of such diagnostic tools, medical or alternatively rehabilitation therapy is initiated to address the diagnosed problem, which, if cured medically or remediated, will enable a person to function as 
independently as possible - within the social and economic environments designed and used by able-bodied persons.

There is a presumption that it is a public good to address social justice and citizenship but only to the extent that it is feasible within the values of the marketplace. Otherwise it belongs to the public domain. But as Mr Juan Somania, Director-General of the International Labour Organization (ILO) asked in a recent address, "Why should the macroeconomic balance be achieved on the basis of unbalancing the lives of people already living in the margins of society?"

As well as the two approaches to disability based on individual pathology, there are two identifiable approaches to disability based on "social pathology". They both start from a presumption that disability is not inherent to the individual. Rather they assume that the disability is a function of the social structure. It is a structural model rather than an individual model, recognizing the pathology as a consequence of social and economic conditions rather than the individual impairment.

The shared characteristics of these are:

- they assume that disability is not inherent to the individual independent of the social structure;

- $\quad$ they give priority to political, social and built environment;

- $\quad$ they emphasize secondary prevention rather than primary treatment;

- $\quad$ they recognize disability as difference rather than as an anomaly;

- $\quad$ they portray the inclusion of people with disabilities as a public responsibility;

- $\quad$ they depict the social, environmental and economic structures as the primary point of intervention. 


\section{Disability as Social Pathology}

Advances in knowledge, based on an understanding of disability as a social pathology, have shown that personal abilities and limitations are the result not only of factors residing in the individual, but also of the interaction between individuals and their environments. This, recognizably, moves disability into the public domain, making problematic the argument that disability is a private responsibility and therefore ought to be privately ameliorated. Social justice would demand that the needs of people who are disadvantaged by the social, economic, legal and political conditions be met through the public domain as part of a package of socially expected public goods.

From an environmental perspective on disability, the policy and program focus is placed on the way the environments are arranged. Increasingly, there is evidence in policy research that the impact of disability can be reduced, as environments are adapted to enable participation.

The handling of disability from this approach is to identify the barriers in society that restrict the participation of people with impairments or disabilities in economic and social life. Structural barriers to independent living or community living become the sites for state intervention (Canadian Association for Independent Living Centres 1994; Roeher, 1988). Prevention then is through the elimination of social, economic and political barriers. The elimination of physical barriers, for example, the building of ramps or the adoption of employment equity or affirmative action policies would be methods of prevention. 
The second of the two systemic approaches presumes that disability has social causes and is a consequence of how society is organized and the relationship of the individual to society at large (see Roth, 1983; Beresford, 1994;Roeher, 1993; Rioux, 1994; ICIDH, 1991). Research, policy and law from a rights-outcome approach, look beyond particular environments to focus on the broad systemic factors keeping some groups of people from participating as equals in society.

From a rights-outcome approach, wide variations in cognitive, sensory and motor ability are seen as inherent to the human condition and consequently, the variations should not limit the potential to contribute to society. It frames disability issues through the lens of principles of social justice. It recognizes that it is a public good to reduce civic inequalities and address social and economic disadvantage. People will need supports (e.g., personal services, aids and devices) in order to gain access to, participate in and exercise self-determination as equals in society. Recognition of social and political entitlements is based on social justice rather than economic contribution and rights are equated with those of all others in society. There is a social good in enabling inclusion and the exercise of citizenship rights (See Figure 3: Understanding Disablity).

Policy from a rights-outcome approach constructs an analysis of how society marginalizes people and assumes that social institutions can be adjusted to respond effectively to the participation and the needs of those who have been systemically marginalized. Treating the disadvantage is seen as a consequence resulting from the reformulation of social and political policy and of recognizing the condition of disability as inherent to society, not some kind of anomaly to normalcy. 
The impact on social policy of how the disadvantage that attaches to disability is characterized is significant. Relieving the state of responsibility for providing for the social well-being of people with disabilities, would mean that social well-being loses the characteristics of public goods of non-excludability and non-rivalness. But if the difference is biology, an argument can be made that the nature of the class of people itself provides justification for the well-being of those in that class to be distinguished from that of others. The public good of well-being can, arguably, still be recognized.

If the difference attached to disability is attributed to social conditions and the social relations in which biology exists, then there is an increased public responsibility to better the conditions through redistributive policies if social well-being and social justice are public goods. It then falls within the public domain to reduce civic inequalities, that is, to address social and economic disadvantage by providing supports to enable social and economic integration, self-determination and legal and social rights. Social justice and equity then are interpreted as political demands that social policy should focus on the disabling aspects of society, on supporting human diversity and on empowering disadvantaged individuals in order to provide well-being .

Figure 2: Understanding Disability from a Societal and Individual Perspective 


1. Individual Pathology (IP): 'Can you tell me
what is wrong with you?'

Social Pathology (SP): 'Can you tell me what is wrong with society?'

2. IP: 'What complaint causes your difficulty in holding, gripping or turning things?'

SP: What defects in the design of everyday equipment like jars, bottles and tins causes you difficulty in holding, gripping or turning them?

\section{IP: Are your difficulties in understanding} people mainly due to a hearing problem?'

SP: Are your difficulties in understanding people mainly due to their inability to communicate with you?'

4. IP: Do you have a scar, blemish or deformity, which limits your daily activities?'
SP: Do other people's reaction to any scar, blemish or deformity you may have limit your daily activities?'

5. IP: Have you attended a special school because of a long-term health problem or disability?'

SP: Have you attended a special school because of you education authority's policy of sending people with your health problem/disability to such places?'

6. IP: Does you health problem/disability prevent you from going out as often or as far as you would like?'

SP: What is it about the local environment that makes it difficult for you to get about in your neighbourhood?'

7. IP: Does your health problem/disability make it difficult for you to travel by bus?' 


SP: 'Are there any transport or financial
problems which prevent you from going out
as often or as far as you would like?'
8. IP: Does your health problem/disability
affect your work in any way at present?'
SP: Do you have problems at work because
of the physical environment or the attitudes
of others?'
9. IP: Does your health problem/disability
mean that you need to live with relatives or
someone else who can help or look after
you?'

else to provide you with the right level of personal assistance?'

10. IP: Does you present accommodation have any adaptations because of your health problem/disability?'

SP: Did the poor design of your house mean that you had to have it adapted to suit your needs?'

Adapted from Barnes et all (1999) p. 29

These social and scientific formulations of disability provide a means to recognize how scientific rationalism has been used to justify political policies and programs that maintain disability as a private rather than a public responsibility - a matter of opportunity cost or economic drain (See Figure 4). 
Figure 4. Scientific rationalism as a legitimating mechanism for determining the public/ private boundary.

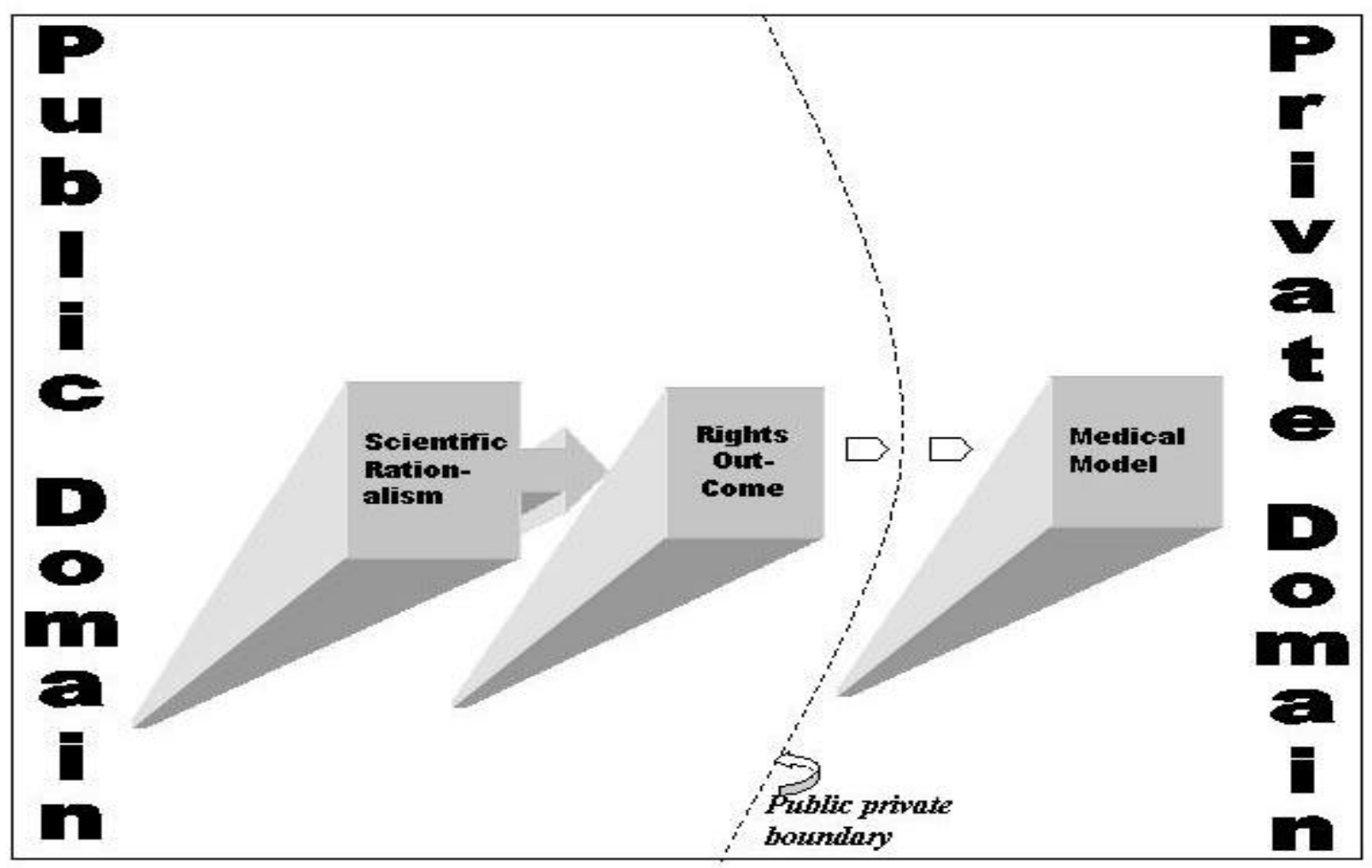

The recognition and elaboration of what determines the lives of those with disabilities and others is useful as a barometer of the construction of the demarcation between the public and private domain and of the impact of economic pressures to reduce redistributive policies. If disability is interpreted as a biological condition, an individual pathology, then there is less imperative for the state to make it an expenditure priority and a necessary condition of social well-being - that is, for it to be treated as a public good. More importantly, policy that provides for the humane treatment of people with disabilities can be characterized as beneficence rather than social justice, and falls 
outside the parameters of the social good, social justice and social well-being. The demand to address it through programs and policies is weakened.

\section{Rethinking the Social}

When disability is recognized as a condition resulting from the social conditions in which biology exists, then the social inequity and the public policy created to respond to it has to take into account state responsibility for social justice and well-being to be recognized as public goods. There are examples of circumstances of disability being recognized as a public responsibility even while the same disabilities are privatized in other circumstances. Disabilities resulting from identifiable conditions such as workplace accidents are generally interpreted as the responsibility of the state in the sense that disability insurance (Workers Compensation) is regulated and administered by the state. Further, programs have been established and paid for by the government to enable return to work. Entitlements to such state programs are commonly dependent on the cause of the disability rather than either the need or the type of disability. There is an inequity built in to social programs for people with disabilities based on the cause of the condition. Some particular medical conditions have led to the acknowledgement of state accountability. For example, the state has, in some cases, been held accountable for the disabled children of mothers who used thalidomide. It is possible that this attaches to health as a social good, rather than social justice or social well-being.

The important point is that, the same condition might, in one case, bring a duty on the state to put in place redistributive policies to ameliorate the disability and in another 
leave the state with no duty. It may depend on the time of the conditions' occurrence (at birth versus in the workplace) or its' cause (genetic versus non-genetic).

If individual biology, for which the state allegedly has neither culpability nor influence, is the determining factor in disability, then it limits the liability and shifts the boundary towards privatization of responsibility and limiting entitlement. It delimits the public domain and increases the private domain. On the other hand, if disability is a consequence of social conditions and social relations in which biology exists, the social disadvantage attached to disability becomes part of the public domain with corresponding duties and obligations to respond. Ensuring the social well-being of those with disabilities is then an intrinsic part of the state's responsibility to ensure social wellbeing for all citizens. It is a public good.

Consequently how a group is differentiated and how the difference is formulated has had an effect on where governments have differentiated between the public and private domains and their consequent social policy. How people are characterized is used as a rationale to shift the boundary between the public and the private domains and the role of the state in ensuring social well-being. Whether the cause of their disadvantage is a result of their own actions or can be characterized as an individual circumstance rather than recognizing the social, political, and economic conditions contributes to the extent the government responds to the disability. Thus social conditions such as inequality, unemployment, social cohesion, health, marginalization and so on can fall into either domain depending on which values predominant.

If the failure of the market, which contributes to inequality, is attributed to individual circumstance, the argument is made to limit the size and role of the state. The 
legitimization of difference is used to limit the public obligation, through privatizing public misfortune, reducing public costs and expenditures.

On the other hand, if the role of the market in creating social exclusion and reducing social well-being is recognized, then it is less feasible for governments to legitimize not building it into the relationship between the economic and social aspects of development. The market cannot be relied upon to correct the imbalances inherent in these values.

The issue of how disability is treated suggests a number of trends. First, the economic pressures of globalization and deficit reduction result in the limitation of government to a minimal agenda of social equilibrium between the individual and the public interest. Second, social policy is being motivated by deficit reduction that diminishes principles of democratization, equality and self-determination. It is a continuing trend towards a narrowing definition of worthy poor and has two impacts: it minimizes state responsibility and in the process increases the inequality in SES, social entitlement and citizenship rights. Third, there is a commodification of resources, including people, which limit the provision of social well-being as a public good. Standards of economic efficiency and scientific rationality are used to set the barrier of what the state is prepared to recognize within the context of social justice and well-being as public goods.

\section{Conclusion}


The ambiguities involved in efforts to determine what is public and what is private are not insignificant. And because where the boundary falls is a consequence of economic, social and legal pressures, the boundary between the public and private domain is dynamic. Attempts to clarify, by definition, what is a public good have simply highlighted the ambiguity. The politics of welfare and of provision for the disabled population has been about shifting responsibilities from one sector to another. The achievement of social well-being as a public good and the consequent provision of welfare are the products of struggle by various interests and are the result of the balance that emerges from a struggle for recognition, legitimacy, resources and autonomy. However, if social well-being and social justice are public goods, then there is a need to be cautious about assumptions that shifting the responsibility for some functions of welfare and for some disability from the public sector to the private sector will not result in inequalities, reduction of health status, and limitation of social citizenship. Retrenchment and disentitlement can have serious consequences, even where legitimized by economic determinism, utilitarianism and scientific rationalism.

As governments shift the boundaries of what is within the public domain, they legitimate their decisions as having some objective claim. The pressures of globalization have had a significant impact in shifting understanding of what is the content of a public good and ought therefore to be public responsibility.

Disability is an area that is particularly sensitive to the changing position of the boundary between the public and private domain. It is an indicator of how states conceive of social justice as a public good and the economics of social responsibility. There are two forces that underlie the shift. The first is economic determinism (that is a 
function of such phenomena as market values) and the second is a function of scientific rationalism (that is a function of the belief in the ability of the "technological" sector to solve both physical and social problems). The pressures to define the public domain within the framework of globalization, deficit reduction and market dominance raise serious issues about social well-being as a public good. Not only have governments shown themselves willing to adopt an international economic agenda but also they have quite creatively legitimized the privatization of individual misfortune. Collective responsibility is sacrificed to an economic agenda that offers up the social good as a dispensable commodity.

Globalization has not succeeded in making markets work for all. The benefits have been unevenly distributed both between and within states and among various groups. Juan Somavia, Director-General of the ILO concluded in a recent speech “... globalization's failure to deliver a steadily increasing number of productive jobs is the result of inadequacies in international and national policies and implementation. The solution must recognize that improved financial system architecture cannot replace the need for effective domestic policies"(Somavia, 2000).

The notion of public goods, in cohesive societies, has, historically, been articulated in values and policies distinct from, and that may even conflict with, those of the individual interests in the marketplace. There are however compatibilities of social well-being and economic well-being. Managing markets should not come at the expense of the common goods of social justice and social well-being.

\section{Endnotes}


${ }^{1}$ A realist view dominated this Cold War period in which the national interest was defined as the acquiring of sufficient power to ensure survival.

${ }^{2}$ Government bureaucrats began to acknowledge the role that continuous economic development, human rights, social equity and essential freedoms had in the maintenance of peace and provision of security.

${ }^{3}$ In the $19^{\text {th }}$ century, alternatives to laissez-faire and the status quo of widespread poverty and suffering had led to the promotion of alternate political and economic models.

${ }^{4}$ Well-being is a dynamic relationship between; on the one hand, an individual's developing capacities and sense of purpose and, on the other, the changing social, cultural, and economic conditions that affect the pursuit and achievement of a person's aims. At an individual level, well-being entails the support by other individuals, communities and society to exercise self-determination, to recognize respect and to accommodate the aims of others. Individuals cannot attain well-being by themselves but do so in the context of the communities to which they belong, communities defined by common heritage, language, culture, gender, geography or interests.

${ }^{5} 1834$ revision of the Elizabethan Poor Laws. This principle required the public support for an individual guarantees a lower standard of living than that of the poorest paid labourer. 
${ }^{6}$ The cracks in the post-War framework and subsequent pressure for its restructuring gained momentum form the 1960's to the 1980's - first from the civil rights movement, from the women's movement and later from other movements of marginalized people. The obligations found in statutory and regulatory human rights protections contributed to a new understanding of what constituted social well-being as a public good. It built on the post-War framework and expanded the understanding of social well-being. This brought into question some of the underlying assumptions about what was private and what was public, in particular that of the worthy/unworthy poor distinction. The reinvented notion of social well-being and progress that was articulated as a public good incorporated the importance of social justice, human rights and social solidarity. The 1980 's saw a retrenchment of this trend.

\section{References}

Barnes, C., Geof Mercer, and Tom Shakespeare (1999) Exploring Disability: A Sociological Introduction, Polity Press, Cambridge.

Beresford, P. a. J. C. (1994) Disability and Society, 9, 315-325.

Bowles, G. a. (1986) Canada, L. R. C. o. (1979) Sterilization: Implications for Mentally Retarded and Mentally III Persons, Minister of Supply and Services Canada, Ottawa. Cohen, S. (1985) Visions of Social Control: Crime, Punishment and Classification, Polity Press, Cambridge.

Cohen, S. a. A. S. (Ed.) (1983) Social Control and the State, Martin Robertson, Oxford. 
Drache, D. (1999.) In Governing the Public Domain Beyond the Era of the Washington Consensus? Drawing the Line between the State and the Market. (Ed, Drache, D.) York University, Toronto.

Esping-Andersen, G. (1985) Politics against markets: the social democratic road to power, Princeton University Press, Princeton, N.J.

Grayson, K. (1999) In Governing the Public Domain Beyond the Era of the Washington Consensus? Redrawing the Line Between the State and the Market, (Ed, Drache, D.) York University Ontario.

Guest, D. (1980) The emergence of social security in Canada, University of British Columbia Press,, Vancouver.

ICIDH, C. S. f. (1991) ICIDH International Network, 4.

Kapstein, E. B. (1999) In Global Public Goods: International Cooperation in the 21st Century (Ed, Kaul, I., Isabelle Grunberg, Marc A. Stern) Oxford University Press, Oxford, pp. 88-115.

Katz, M. B. (1986) In the Shadow of the Poor House: A Social History of Welfare in America, Basic Books Inc., New York.

Kaul, I., Isabelle Grunberg, Marc A. Stern (1999) Global Public Goods: International Cooperation in the 21st Century, United Nations Development Program, New York. Korpi, W. (1983) The democratic class struggle, Routledge \& K. Paul, London; Boston. Kuttner, R. (1984) The economic illusion: false choices between prosperity and social justice, Houghton Mifflin, Boston.

Laurell, W. a. (1994). 
Lukes, S. (1980) In Justice Alternative Political Perspectives(Ed, Sterba, J.) Wadsworth Publishing House. Belmont, California.

Mackelprang, R. a. R. S. (1999) Disability: A Diversity Model Approach in Human Service Practice, Brooks/Cole Publishing Company, Toronto.

Marshall, T. H. and Bottomore, T. B. (1992) Citizenship and social class, Pluto Press, London; Concord, Mass.

Mishra, R. (1984) The welfare state in crisis: social thought and social change, Wheatsheaf Books, Brighton, Sussex.

Mishra, R. (1990) The welfare state in capitalist society: policies of retrenchment and maintenance in Europe, North America and Australia, Harvester Wheatsheaf, New York; London.

Myles, J. (1991) In The New Era Of Global Competition: State Policy And Market Power (Ed, Daniel Drache and Meric Gertler ed) McGill-Queen's University Press, Montreal. Osberg, L. (1990) Department of Economics, Dalhousie University, Halifx. Rao, M. (1999a) In Global Public Goods: International Cooperation in the 21st Century (Ed, Kaul, I., Isabelle Grunberg, Marc A. Stern) United Nations Development Program, New York, pp. 70.

Rao, M. (1999b) In Global Public Goods: International Cooperation in the 21st Century (Ed, Kaul, I., Isabelle Grunberg, Marc A. Stern) United Nations Development Program, New York, pp. 7.

Rawls, J. (1971) A theory of justice, Belknap Press of Harvard University Press, Cambridge, Mass. Rioux, M. H. a. M. B. (Ed.) (1994) Disability is not measles: new research paradigms in disability, Roeher, North York. 
Roeher, I. (1988) Income Insecurity: The Disability Income in Canada, Roeher, Toronto.

Roeher, I. (1992) Social Well -Being, Roeher Institute, Toronto.

Roeher, I. (1993) Social Well-Being: Paradigm for Reform, Roeher, Toronto.

Roth, W. (1983) Society, 20.

Ruggie, M. (1984) The State And Working Women: A Comparative Study Of Britain And Sweden, Princeton University Press, Princeton, N.J.

Schoenblum, J. A. (1995.) The American Journal Of Tax Policy, Jeffrey A. Schoenblum Tax Fairness Or Unfairness? A Consideration Of The Philosophical Bases For Unequal Taxation Of Individuals Tax Fairness Or Unfairness?; The American Journal Of Tax Policy;12 Am. J. Tax Pol'y 221; 1995.

-------- Tax Fairness or Unfairness? A Consideration of The Philosophical Bases For Unequal Taxation Of Individuals Tax Fairness Or Unfairness? The American Journal Of Tax Policy;12 Am. J. Tax Policy 221; 1995.

Sen, A. (1999a) Development as Freedom, Oxford University Press, Oxford.

--------. (1999b) In Global Public Goods: International Cooperation in the 21st

Century(Ed, Kaul, I., Isabelle Grunberg, Marc A. Stern) United Nations Development Program, New York, pp. 116-125.

Service, E. I. (1993) European Social Policy, 35.

Somavia, J. (2000) In Roundtable on Disability and Social Development.

Sutherland, N. (1976) Children in English -Canadian Society, University of Toronto Press, Toronto. Taylor, C. (1992) Multiculturalism and the Politics of Recognition: An Essay, Princeton University Press, Princeton, New Jersey. 